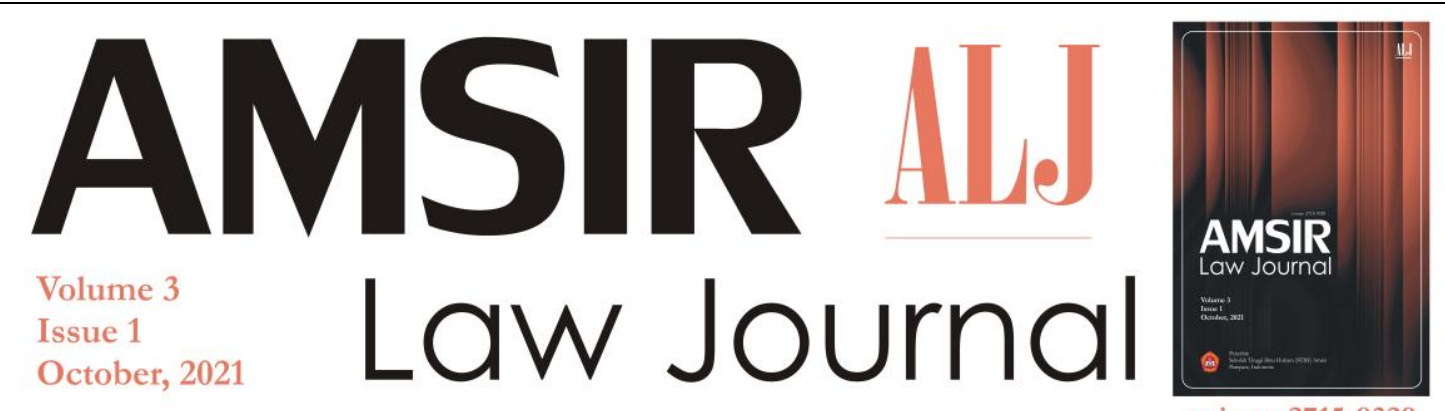

This work is licensed under a Creative Commons Attribution 4.0 International License.

\title{
Konsep Negara Hukum dan Demokrasi dalam Pandangan Abdul Qahhar Mudzakkar
}

\author{
Abbas Abbas ${ }^{1}$.
}

\section{ARTICLE INFO}

\section{Keywords:}

Negara Hukum; Negara Islam;

Demokrasi; Abdul Qabhar

Mudzakear.

How to cite:

Abbas, Abbas. (2021).

Konsep Negara Hukum dan

Demokrasi dalam

Pandangan Abdul Qahhar

Mudzakkar. Amsir Law

Journal, 3(1), 39-50.

DOI:

10.36746/alj.v3i1.49

\begin{abstract}
The research aims to find out about the conception of the state of law and democracy aspired by Abdul Qabhar Mudzakear. The type of research used in this study is the socio-juridical type of research. Juridically because the unit of analysis in this research is an idea, the idea knows the concept. Where in what is meant is an idea Abdul Qabhar Mudzak.kar about the concept of a state of law and democracy. Empirically the author songht to see the historical facts about the application of the concept correlated with the constitution of the Republic of Indonesia in the era of President Soekarno's leadership. The results showed Abdul Qabhar Mudrakkar wanted the Indonesian state as an Islamic state with a presidential system of government while still carrying out the principles of true democracy. True democracy means Abdul Qabhar Mudzakkar is a tribute to the values of martyrdom, pluralism, and justice. This certainly requires better time, methods, and refinements if you want to be applied in a plural Indonesia.
\end{abstract}

Copyright (C) 2021 ALJ. All rights reserved.

\section{Pendahuluan}

Pasca reformasi tahun 1998 sistem ketatanegaraan Indonesia mengalami perubahan yang sangat mendasar. Ruang-ruang demokrasi sangat terbuka lebar bagi setiap kelompok masyarakat untuk berperan serta di dalam sistem pemerintahan, yang sekian lama-semasa orde baru-kebebasan itu, sangat sulit didapatkan.

Salah satu hal mendasar dan menjadi perhatian bagi sebagian umat Islam adalah mengembalikan amanah Piagam Jakarta ke dalam konstitusi Indonesia, terutama menyangkut tujuh kata pada Piagam Jakarta: "dengan kewajiban menjalankan syariat Islam bagi pemelukpemeluknya." Pada era kepemimpinan Presiden Abdurrahman Wahid (Gus Dur), di saat-saat terjadi perseteruan konflik ${ }^{2}$ antara eksekutif dan legislatif, sekelompok golongan Islam ingin

${ }_{1}$ Fakultas Hukum, Universitas Megabuana Palopo, Palopo, Indonesia. E-mail: abbasdjohan@gmail.com

2 Purwanda, S. (2014). Model Penanggulangan Konflik Dalam Perspektif Socio-legal (studi Kasus Tawuran Mahasiswa Dikota Makassar) Conflict Management Model in Socio-legal Perspective (Study Case of Student Brawl in Makassar). $L A W$ REFORM, 10(1), 125-152. 
mempertahankan kepemimpinan Presiden Gus Dur dengan berbagai cara, namun dengan syarat ideologi negara (Pancasila) diganti dengan ideologi Islam serta menjadikan Indonesia sebagai Negara Islam, yang pada akhirnya hal itu ditolak oleh Gus Dur sendiri. Namun gerakan golongan Islam ini terus berlanjut. ${ }^{3}$

Berbagai gerakan moral dan diskusi-diskusi, seminar, lokakarya dan sebagainya dilakukan dalam meretas hubungan antara islam dan negara. Ada yang tetap berkeinginan memasukkan tujuh kata tersebut ke dalam konstitusi, ada yang sedikit demokratis untuk mencari jalan tengahnya dan ada pula yang cenderung liberal untuk tidak menghubunghubungkan keterkaitan antara negara dan Islam.

Bagi yang ingin memasukkan tujuh kata tersebut ke dalam konstitusi dengan tujuan agar negara Indonesia dapat menjadi negara Islam, ini dikarenakan beberapa alasan. Pertama, sejarah konstitusi Indonesia yang awalnya berasal dari Piagam Jakarta, telah disepakati oleh Badan Penyelidik Usaha Persiapan Kemerdekaan Indonesia (BPUPKI), tetapi pada akhirnya di dalam rapat konstituante penetapan Undang-undang Dasar Tahun 1945 tersebut, jauh berubah dari kesepakatan awal yang menyebabkan kelompok Islam sedikit kecewa. ${ }^{4}$ Kedua, Beberapa daerah di tanah air menginginkan syariat Islam berlaku sebagai solusi dalam memecahkan problem kebangsaan yang terjadi saat itu. Ketiga, tokoh-tokoh perjuangan pergerakan kemerdekaan Indonesia juga menginginkan agar Indonesia dapat menjadi negara Islam. Di antara tokoh-tokoh tersebut adalah Muh Natsir, Wahid Hasyim, Abdul Qahhar Mudzakkir, Ki Bagoes Hadikusumo, Abdul Qahhar Mudzakkar, Muhammad Daud Beureu, S. M. Kartosoewiryo, Burhanuddin Harahap dan lain sebagainya.

Masa reformasi saat ini sangat terbuka lebar, kebebasan setiap individu sangat dihargai, peran serta masyarakat di dalam sistem pemerintahan dan politik diperlukan dalam rangka penguatan demokrasi, dan atas dasar itu pula gerakan sebagian umat Islam kembali ingin mengamandemen konstitusi Indonesia agar tujuh kata yang terdapat di dalam Piagam Jakarta dapat diakomodir dan dimasukkan kembali dalam konstitusi negara Indonesia.

Sulawesi Selatan salah satu daerah yang aktif melakukan baik dalam bentuk gerakan moral maupun dalam bentuk diskusi-diskusi, dialog, seminar, lokakarya dan lain sebagainya dalam rangka mendialogkan Piagam Jakarta tersebut. Tentang ideologi negara Islam, terdapat hal yang menarik untuk dicermati khususnya di Sulawesi Selatan, bahwa setiap gerakan dan tindakan untuk mengamandemen konstitusi kembali ke Piagam Jakarta atau menjadikan negara Indonesia sebagai negara Islam selalu dilekatkan pada sejarah gerakan Darul Islam/Tentara Islam Indoenesia (DI/TII) oleh Abdul Qahhar Mudzakkar di Sulawesi Selatan juga karena Abdul Qahhar Mudzakkar menjadi tokoh bagi sebagian kalangan hingga saat ini (terutama keluarga dan para pengikut-pengikutnya terdahulu).

Bagi Abdul Qahhar Mudzakkar syariat Islam haruslah berlaku sebagai hukum negara untuk mencegah dan mengatasi problem kebangsaan yang terjadi saat ini. Bagi Abdul Qahhar Mudzakkar sistem Negara Islam adalah konsep ketetanegaraan yang paling ideal untuk diterapkan di Indonesia dan tidak ada alasan bagi pemerintah maupun elit politik untuk tidak menyetujuinya sebab mayoritas penduduk Indonesia 90\% beragama Islam.

\footnotetext{
3 Peristiwa detik-detik kejatuhan Presiden Abdurrahaman Wahid, terdapat sekelompok golongan Islam dari berbagai daerah menghadap ke Istana Presiden untuk siap mengerahkan kekuatan massa Islam dalam mempertahankan kepemimpinan Gus Dur dengan syarat mengganti ideologi Pancasila dengan ideologi Islam, hal ini diutarakan oleh Mahfud MD saat wawancara di Chanel TV Impac Jakarta.

${ }^{4}$ Menguraikan panjang lebar tentang proses perdebatan Piagam Jakarta sampai kesepakatan lahirnya Undang-Undang Dasar Tahun 1945. Dijelaskannya terdapat golongan Nasionalis dan golongan Islam sangat berperan di dalam penentuan detikdetik akhir kesepakatan Undang-undang Dasar Tahun 1945 tersebut. Moh. Mahfud MD, (2001), Dasar dan Struktur Ketatanegaraan Indonesia, Jakarta: Rineka Cipta, hlm. 40-50.
} 
Berbicara tentang demokrasi bagi Abdul Qahhar Mudzakkar menganggapnya bukanlah hal yang bertentangan dengan Islam karena demokrasi sejati sejalan dengan cita-cita Islam. Sayangnya demokrasi yang dipahami oleh sebagian kalangan adalah demokrasi rasio yang berasal dari dunia barat yang lupa akan demokrasi sejati yaitu demokrasi yang digariskan oleh Tuhan di dalam kitab Suci Al-Qur'an yang tegas menyatakan bahwa kedaulatan dan kekuasaan itu mutlak ada pada Tuhan. ${ }^{5}$

Islam dalam pandangan Abdul Qahhar Mudzakkar adalah sistem ketatanegaraan dan politik yang sangat sempurna, sehingga kewajiban bagi setiap pemeluknya untuk menegakkan dan menjalankan syariat Islam di dalam segala aspek kehidupan berbangsa dan bernegara. Pemeluk agama Islam yang masih mempertanyakan konsep negara Islam tersebut adalah hal yang kurang tepat.

Baginya prinsip-prinsip di dalam hukum Islam sebagai pedoman hidup sangatlah jelas dan tegas sehingga menerapkan hukum selain hukum yang diperintahkan oleh agama (Tuhan) adalah dosa besar dan hal itu sama dengan menantang kekuasaan Tuhan. Bagi orang yang beragama tidak ada hukum lain yang baik selain hukum Islam. Sangat ironis umat yang mengaku beragama Islam namun tidak menegakkan hukum Islam sebagai landasan bernegara, "...kita tolak ajaran agama sebagai dasar negara, pada hal kita semua mengaku beragama."

Abdul Qahhar Mudzakkar di dalam ideologi dan konsep yang digagasnya mencitacitakan Negara Hukum yang berdasarkan syariat Islam, rahmat bagi semua golongan suku bangsa yang akan mendatangkan kebahagian bukan hanya pada pemeluknya namun kepada semua agama lain. "Dalam Masyarakat Indonesia dengan susunan kenegaraan seperti ini, segenap golongan Suku Bangsa tetap berdiri dengan corak kebangsaannya sendiri-sendiri, rukun dan damai menjalankan Syariat Agama yang dianut masing-masing, dan Syariat Agama itulah yang menjadi 'titik persatuan' Bangsa Indonesia seluruhnya, dalam lingkungan Negara Persatuan Indonesia Raya. Susunan masyarakat kebangsaan beragama demokratis, yang dijiwai oleh Syari'at Agama dan dipagari oleh Semangat Kebangsaan Al-Hudjurat Ayat 13 yang elok, lagi cantik molek, tidak saja dapat menggalang Persatuan Bangsa Indonesia sendiri, akan tetapi juga dapat menggalang Dunia Persaudaraan Manusia, menggalang Dunia Persaudaraan Islam, menggalang Dunia Persaudaraan Nasrani, menggalang Dunia Persaudaraan Hindu-Budha..."”

Saat awal pergerakan Abdul Qahhar Mudzakkar mendirikan Negara Islam Indonesia ia masih mengagumi bentuk Negara Kesatuan, namun dalam perjalanan gerakannya terutama saat-saat pemerintah Indonesia mendapat perlawanan ideologi dari berbagai kelompok dan wilayah diantaranya Syafruddin Prawiranegara, Muhammad Natsir, S. M. Kartosoewiryo dan Muh. Daud Beureu, mereka membuka ruang komunikasi dan kesepakatan mendirikan Negara Perstuan Republik Indonesia (PRI). Dalam Undang-undang Dasar PRI digambarkan bentuk negara yang ideal yang diterapkan di Negara Indonesia sebagai bentuk Negara Bagian yang didasarkan terhadap pengakuan pada berbagai golongan dan aliran kepercayaan agama masing-masing dalam kerangka Negara Kebangsaan Persatuan Indonesa Raya. ${ }^{8}$

Negara hukum menempatkan keadilan dan persamaan hak adalah nilai yang sangat fundamental sebagai landasan di dalam menjalankan roda pemerintahan. Tanpa adanya

${ }^{5}$ Muzakar, A. K. (1999). Konsepsi negara demokrasi Indonesia: koreksi pemikiran politik pemerintahan Soekarno. Darul Falah, hlm. 123-124.

${ }^{6}$ Muzakar, A. K. (2005). Revolusi ketatanegaraan Indonesia: menudju persaudaraan manusia. toACCAe Publ.. hlm. 54.

${ }^{4}$ Ibid, hlm. 29.

${ }^{8}$ Ibid. 
jaminan negara sebagai negara hukum maka penghargaan terhadap hak asasi manusia dan nilai-nilai demokratisasi tidak mendapat jalan sebagaimana mestinya.

Abdul Qahhar Mudzakkar di dalam konsep Negara Hukum dan Demokrasi sebagai gagasan perjuangannya merumuskannya ke dalam tiga poin utama yaitu:

1) Dasar negara yang tegas, yang dapat menyakinkan segenap pemeluk agama golongan suku bangsa Indonesia atas dasar keyakinan agamanya masing-masing;

2) Sistem pemerintahan yang tertentu dan demokratis; dan

3) Bentuk negara-negara bagian berdasarkan Mitologis-Indonesia dan Juridis-Historis kehidupan masing-masing golongan suku bangsa Indonesia. ${ }^{9}$

Perjuangan Abdul Qahhar Mudzakkar mendirikan negara Islam bukanlah sesuatu hal tanpa alasan. Kepemimpinan di era Presiden Soekarno yang mendapat perlawanan berbagai golongan dikarenakan kepemimpinannya dianggap telah keluar dari cita-cita luhur bangsa Indonesia. Presiden Soekarno merangkul golongan Islam, Nasionalis Sekuler, dan Golongan Komunis yang dikonsepsikannya ke dalam NASAKOM. Konsep ini sangatlah bertentangan dengan keinginan bangsa Indonesia yang mayoritas penduduknya 90\% beragama Islam. Perilaku politik Soekarno pun mendahulukan suku Jawa turut menjadi sebab gerakan perlawanan terhadap kepemimpinannya. Pengisian jabatan, dan pengembangan Sumber Daya Manusia (SDM) lebih mengutamakan orang-orang Jawa. Abdul Qahhar Mudzakkar salah satu tokoh pejuang kemerdekaan menganggap mendapat perlakuan itu, turut dirasakan pula oleh rakyat Sulawesi Selatan yang ikut berjuang merebut kemerdekaan bersamanya saat itu.

Pemerintah telah menetapkan bahwa seluruh pejuang kemerdekaan dari golongan rakyat sipil haruslah diseleksi dan memenuhi syarat untuk masuk menjadi anggota Tentara Nasional Indonesia (TNI). Namun hal ini berbeda dengan keinginan rakyat sipil yang ikut berjuang merebut kemerdekaan khususnya yang tergabung dalam Kesatuan Gerilya Sulawesi Selatan (KGSS) yang berjumlah sekitar 800 orang, agar mereka tidak diseleksi masuk ke dalam TNI karena bagi mereka jika persyaratan itu diterapkan tentu hanya sebagian anggota KGSS yang memenuhinya seperti tinggi badan, lebar dada, tidak mempunyai cacat tubuh, cakap baca tulis dan fasih berbahasa Indonesia. Dari sinilah bermula perseteruan antara kelompok KGSS dan tentara Indonesia yang semakin memuncak.

Abdul Qahhar Mudzakkar memberikan solusi kiranya pemerintah dapat mengangkat mereka seluruhnya menjadi anggota TNI sebagai penghargaan atas jasa dan perjuangannya dalam merebut kemerdekaan Indonesia. Akhirnya tawaran Abdul Qahhar Mudzakkar ini pun tidak diterima oleh pemerintah, menyebabkannya meninggalkan institusi TNI dan bergabung kembali bersama-sama dengan kelompok KGSS.

Setelah Abdul Qahhar Mudzakkar meninggalkan institusi TNI dan kembali bergabung dengan kelompok yang dibentuknya saat-saat merebut kemerdekaan Indonesia, mulailah mengadakan perlawanan kepada pemerintah yang dianggapnya telah jauh dan menyimpang dari cita-cita luhur bangsa Indonesia. Baginya untuk mengatasi semua problem kebangsaan Indonesia hanya satu cara yaitu kembali kepada ajaran agama dan sunah Rasulullah.

Dalam perjalanannya setelah keluar dari tentara Indonesia, Abdul Qahhar Mudzakkar selanjutnya mencetuskan berdirinya Negara Islam Indonesia (NII) sebagai solusi mengatasi problem kebangsaan yang terjadi. Konsep negara hukum dan demokrasi yang ditafsirkannya melalui ajaran-ajaran agama Islam sangatlah ideal untuk diterapkan di Indonesia.

\footnotetext{
${ }_{9}^{9}$ Muzakar, A. K. (1999). Op.Cit., hlm. 106.
} 
Mengembalikan kedaulatan itu kepada Tuhan, manusia hanya menjalankan ketetapan dan ketentuan-ketentuan dari Tuhan, baik secara individu maupun bebangsa dan bernegara.

Mempelajari latar belakang tersebut maka penulis tertarik untuk menganalisa lebih jauh tentang konsepsi gagasan Abdul Qahhar Mudzakkar yang menganggap gagasan dan idenya sangat ideal dan baik untuk diterapkan di Indonesia karna sesuai dengan filosofi dan budaya bangsa Indonesia. Dengan aksentuasi di atas maka peneltian ini tidaklah membahas prokontra di kalangan masyarakat tentang keberadaannya, namun penulis ingin memfokuskan untuk menganalisa konsep negara hukum dan demokrasi yang dikonsepsikan oleh Abdul Qahhar Mudzakkar.

\section{Metode}

Tipe Penelitian yang digunakan dalam penelitian ini adalah tipe penelitian sosio-yuridis. Secara yuridis dikarenakan yang menjadi unit of analysis di dalam penelitian ini adalah gagasan, ide atau konsep. Dimana dalam hal yang dimaksudkan adalah suatu gagasan (ide) Abdul Qahhar Mudzakkar tentang konsep Negara Hukum dan Demokrasi. Secara empiris penulis berusaha melihat fakta-fakta sejarah tentang penerapan konsep tersebut dikorelasikan dengan konstitusi Republik Indonesia di era kepemimpinan Presiden Soekarno. ${ }^{10}$ Adapun pendekatan penelitian yang dilakukan adalah pendekatan analitis (analytical approacb), pendekatan perbandingan (comparative approach), pendekatan konseptual (conceptual approach), dan pendekatan historis (bistorical approach).

\section{Konsep Negara Hukum dan Demokrasi menurut Abdul Qahhar Mudzakkar}

Abdul Qahhar Mudzakkar mempunyai tujuan dan gagasan agar Negara Indonesia menerapkan hukum Islam sebagai hukum negara dengan kata lain bahwa segala sesuatunya disandarkan kepada "Kedaulatan Tuhan". Maksud dari "Kedaulatan Tuhan" agar segala tindakan dan roda pemerintahan harus berdasar pada ketetapan dan perintah-perintah yang telah digariskan oleh Tuhan yaitu di dalam Al-Qur'an dan Hadis Nabi. Tidak ada hak dan kewenangan manusia untuk tidak melaksanakan "Kedaulatan Tuhan" itu.

Pemerintah sebagai perpanjangan tangan atas hukum-hukum Tuhan. Hal perbedaan pendapat apa dan bagaimana hukum Islam itu dijalankan akan dikembalikan kepada pemerintah sebagai penjelmaan perpanjangan tangan dari Tuhan untuk bermusyawarah dan menetapkannya dengan syarat bahwa segala keputusan harus mempunyai landasan yang kuat dari Al-Qur'an dan Hadis Nabi Muhammmad SAW. Hal ini dapat dilihat pula dalam surah Annisaa ayat 59, yang artinya: "Hai orang-orang yang beriman, taatilah Allah dan taatilah Rasul (Nya), dan ulil amri di antara kamu. kemudian jika kamu berlainan Pendapat tentang sesuatu, maka kembalikanlah ia kepada Allah (Al Qur'an) dan Rasul (sunah-nya), jika kamu benar-benar beriman kepada Allah dan hari kemudian, yang demikian itu lebih utama (bagimu) dan lebih baik akibatnya".

Hal ini pun diuraikan Azis Abdul Qahhar Mudzakkar saat wawancara yang mengatakan bahwa:" “...Bapak Qahhar menginginkan syariat Islam dijalankan dan dijadikan sebagai ideologi negara, dan mengenai perbedaan mazhab dan aliran hal itu dapat dimusyawarahkan." Sejalan dengan hal tersebut, pandangan Abu A'la Al-Mawdudi pun melihat Negara Islam dengan empat prinsip yaitu, Pertama, negara mengakui kedaulatan Tuhan. Kedua, menerima otoritas Nabi Muhammad SAW sebagai "Wakil Tuhan" dan. Ketiga, menerapkan

${ }^{10}$ Jonaedi Efendi, S. H. I., Johnny Ibrahim, S. H., \& SE, M. (2018). Metode Penelitian Hukum: Normatif dan Empiris. Prenada Media. hlm. 300.

11 Wawancara Azis Qahhar Mudzakkar pada tanggal 30 April 2012. 
musyawarah. Dengan demikian Negara berfungsi sebagai alat untuk menerapkan hukumhukum Tuhan.

Ada dua hal pokok yang mendasar dari prinsip gagasan perjuangan Abdul Qahhar Mudzakkar selama kurang lebih 15 tahun mendirikan NII yaitu:

1) Ideologi Negara yang harus diperjelas dan ditegaskan berdasarkan suku bangsa Indonesia.

2) Pemerintah sesegera mungkin mendekritkan untuk membubarkan dan tidak memberikan ruang kepada partai komunis dan ajaran-ajarannya tumbuh dan berkembang di Indonesia.

Sejalan dengan itu menurut A. Oddang (Mantan Panglima Kodam VII Wirabuana Makassar) saat wawancara mengatakan bahwa: ${ }^{12}$ “...perjuangan Qahhar itu salah satunya adalah ingin menghilangkan partai komunis dan pengikut-pengikutnya di mana keberadaannya saat itu diakui oleh pemerintah, sehingga masyarakat yang anti komunis pun akhirnya ikut dan masuk dalam kelompok Abdul Qahhar Mudzakkar.”

Diakuinya partai komunis sebagai bagian dari partai yang resmi oleh pemerintah maka hal itu tidak sejalan dengan keinginan dan gagasan Abdul Qahhar Mudzakkar yang sejak semula menginginkan diterapkannya syariat Islam di Indonesia, dengan adanya partai komunis maka hal itu pasti menghambat perjuangan dan cita-cita yang digagasnya.

Keinginan Abdul Qahhar Mudzakkar mengganti ideologi Pancasila dengan negara Islam bagi sebagian orang dianggap karena kekecewaannya terhadap Presiden Soekarno atas tidak diakomodirnya keinginan membentuk resimen tersendiri dan ia sebagai pimpinan. Atas dasar itu pula lalu mengambil ideologi Islam sebagai perjuangan agar dapat simpatik dari berbagai kalangan. Perjuangan yang membawa misi ideologi merupakan salah satu cara dalam menarik kelompok masyarakat. Hal ini pun diakui Armin Mustamin Toputiri dalam wawancara yang mengatakan bahwa: ${ }^{13}$ “...perjuangan atau gagasan Negara Islam oleh Abdul Qahhar Mudzakkar itu tidaklah murni berangkat dari kesadaran konsepsinya, melainkan disebabkan kekecewaannya terhadap soekarno sehingga ia membentuk NII, dengan demikian maka rakyat Sulawesi akan simpatik dan mengikuti langkah-langkahnya, hal itu dikarenakan "bendera" ideologi yang dibawa oleh Abdul Qahhar Mudzakkar yaitu islam."

Menanggapi hal tersebut, dalam wawancara dengan Nurdin Pisau ia membantahnya dan mengatakan bahwa ${ }^{14}$ "...banyak yang menggap bahwa karena kekecewanlah pada Soekarno lalu Abdul Qahhar Mudzakkar mendirikan Negara Islam dan keluar dari Tentara, padahal jauh sebelumnya saat Qahhar masih di Yogyakarta dia pernah mengutarakan agar sebaiknya Indonesia dijadikan sebagai Negara Islam."

Bagi Abdul Qahhar Mudzakkar, Negara Islam adalah sistem yang sangat ideal bagi Rakyat Indonesia, di samping dikarenakan mayoritas penduduknya beragama Islam juga karena faktor sejarah, di mana saat pembentukan BPUPKI mayoritas memasukkan tujuh kata ini "dengan kewajiban menjalankan syariat Islam bagi pemeluk-pemeluknya" ke dalam konstitusi negara. Hal ini sudah menandakan bahwa sebagian penggagas kemerdekaan saat itu menginginkan adanya syariat Islam dijalankan.

Mengenai tawaran Abdul Qahhar Mudzakkar kepada Presiden Soekarno, ia memberikan usul melalui surat yag ditulisnya sendiri tertanggal 10 Rabiul Akhir $1381 \mathrm{H}$. yaitu, agar Presiden Soekarno segera mengeluarkan dekrit menggantikan Pancasila dengan falsafah

12 Wawancara bersama A. Oddang Pada Tanggal 1 Mei 2012.

13 Wawancara bersama Armin Mustamin Toputiri pada tanggal 29 Oktober 2012.

14 Wawancara bersama Nurdin Pisau pada tanggal 12 Mei 2012. 
ke-Tuhan-an yaitu ajaran Islam yang dianut mayoritas masyarakat bangsa Indonesia, dan agar presiden Soekarno dapat segera mendekritkan pelenyapan komunis di Indonesia beserta ajaran dan pengikut-pengikutnya.

Abdul Qahhar Mudzakkar menjelaskan maksud dari dua poin di atas pada prinsipnya menginginkan falsafah Pancasila ditinjau dan di jiwai ajaran agama, sepanjang ajaran agama yang ada di Indonesia. Serta komunis dilenyapkan di Indonesia baik partai maupun ajaranajarannya. Ia tidaklah bermaksud menggantikan Pancasila dengan lima dasarnya namun dengan tujuan menjiwai Pancasila itu dengan jiwa agamanya misalnya: ${ }^{15}$

1) Sila ketuhanan Yang Maha Esa, diganti dengan sila; Ajaran Islam (berdasarkan AlQur'an dan hadits Sahih) dan Ajaran Agama lainnya yang dianut oleh segenap Golongan Suku Bangsa Indonesia.

2) Sila Kedaulatan Rakyat, diganti dengan sila "demokrasi sejati" berdasarkan Ajaran islam dan ajaran agama lainnya juga dianut oleh segenap golongan suku Bangsa Indonesia.

3) Sila keadilan sosial, ditambah dengan kalimat "berdasarkan ajaran Islam dan ajaran agama lainnya yang dianut oleh segenap golongan suku Bangsa Indonesia.

Dapat dilihat bahwa gagasan Abdul Qahhar Mudzakkar dalam negara hukum ingin menyatukan antara negara dengan agama, yang bagi Din Syamsuddin menterjemahkan sebagai paradigma integralistik dalam hubungan relasi negara dan agama. Dimana agama bagian dari kehidupan bernegara dan berbangsa.

\section{Demokrasi, Bentuk Negara, dan Sistem Pemerintahan Presidensial}

Merumuskan tentang "demokrasi” Abdul Qahhar Mudzakkar tidak sependapat dengan Presiden Soekarno. Bagi Abdul Qahhar Mudzakkar, demokrasi harus mempunyai "batas kedaulatan". Demokrasi tidak dapat dibiarkan disalahtafsirkan oleh penguasa sehingga menyebabkan terjadinya penindasan dan kediktatoran. Batas kedaulatan dalam demokrasi yang dimaksudkan oleh Abdul Qahhar Mudzakkar yakni antara Tuhan dan pemerintah selaku pelaksana amanah Tuhan. ${ }^{16}$

Demokrasi mempunyai "batas kedaulatan". Demokrasi sejati adalah demokrasi apa yang dikatakan Al-Qur'an dan Hadis yang harus dilaksanakan oleh manusia. Tidak ada kebebasan mutlak dimiliki oleh manusia segala sesuatunya hanya Tuhan yang menentukan, manusia hanya menjalankan saja. Kebebasan mutlak ada pada Tuhan, manusia tidak mutlak dikarenakan sifat takdir dan ketetapan yang dimiliki oleh Tuhan. Menurut Abdul Qahhar Mudzakkar "Batas Kedaulatan" dalam demokrasi sejati adalah: ${ }^{17}$

1) Tuhan berdaulat, Tuhan berkuasa, dan Tuhan mempunyai kedaulatan hukum atas segala segi hidup manusia. Kedaulatan hukum Tuhan itu diamanahkan kepada manusia berupa hukum pergaulan hidup manusia dimuka bumi, yang wajib dilaksanakan oleh manusia, baik golongan manusia yang "memerintah", maupun golongan manusia yang "diperintah".

2) Golongan manusia yang memerintah dinamakan "ulil amri", atau Pemerintah; memegang amanah kekuasaan Tuhan melaksanakan hukum Tuhan atas segala manusia yang ada di bawah pemerintahnya dan memegang kebijaksanaan pemerintahan (belied politik) atas negara.

15 Muzakar, A. K. (2005). Op.Cit., hlm. 54-55.

${ }^{16}$ Muzakar, A. K. (1999). Op.Cit., hlm. 121-122.

${ }^{17}$ Ibid, hlm. 125-126. 
3) Golongan manusia yang diperintah dinamakan "ummat", atau rakyat, memegang kekuasaan amanah kekuasaan Tuhan dan memegang kekuasaan kebijaksanaan pemerintahan atas negara dalam melaksanakan hukum kedaulatan Tuhan.

Demokrasi sejati yang diistilahkan oleh Abdul Qahhar Mudzakkar sering diperlawankan dengan liberal demokrasi, diktator demokrasi, fasis demokrasi atau demokrasi nazi, sosial demokrasi dan demokrasi terpimpin yang kesemuanya digolongkan ke dalam demokrasi rasio yang tidak sejalan dengan Islam. Bagi Aswar Hasan melihat ada tiga poin utama arti dari "demokrasi sejati" yaitu: penghargaan terhadap ketauhidan, pluralitas dan keadilan. $^{18}$

Abdul Qahhar Mudzakkar menempatkan demokrasi sejati sebagai amanah menjalankan perintah-perintah tuhan dalam berbangsa dan bernegara. Ia mencontohkan di dunia barat dan dunia Arab kedua-duanya menjalankan apa yang menjadi ideologi agama mereka. Dunia barat yang mayoritas berpenduduk Kristen menjalankan nilai-nilai Kristen dan hidup dalam bentuk masyarakat Kristen begitupun dunia arab hidup dan menjalankan nilai-nilai agama Islam dalam berbangsa dan bernegara. Indonesia yang berpenduduk mayoritas beragama islam dan penduduknya adalah ummat yang beragama maka demokrasi sejati bagi Abdul Qahhar Mudzakkar menjalankan nilai-nilai agama dalam benegara dan berbangsa sesuai dengan agama dan kepercayaan masing-masing pemeluknya. Bagi Abu A'la Maududi hal ini diartikan sebagai "teo demokrasi" karna menjalankan syariat agama yang mencerminkan nilai-nilai demokrasi. ${ }^{19}$

Bentuk Negara yang menjadi gagasan Abdul Qahhar Mudzakkar tidaklah menjadi persoalan utama dalam menjalankan syariat Islam selama hal itu telah digariskan dalam $\mathrm{Al}$ Qur'an dan tidak memisahkan persoalan agama dan negara. Yang bagi Abu Al-Maududi dikatakan sebagai bagian yang integralistik. Dalam hal ini pun Abdul Qahhar Mudzakkar tidak sependapat dengan pidato Presiden Soekarno yang melihat dan mencontohkan negara Turki sebagai negara yang berhasil memisahkan antara agama. Sehingga sangat jelas bahwa Presiden Soekarno menginginkan adanya pemisahan antara negara dan agama dan hal ini tentu tidak sejalan dengan gagasan Abdul Qahhar Mudzakkar yang menginginkan hukum syariat islam yang dijalankan sebagaimana yang diakutip surah Al-Maidah ayat: 50 yang artinya: "Apakah hukum jahiliyah yang mereka kehendaki, dan (hukum) siapakah yang lebih baik daripada (hukum) Allah bagi orang-orang yang yakin”.

Tentang bentuk negara sejak semula Abdul Qahhar Mudzakkar berpandangan dan menganut paham negara kesatuan hal ini dapat dilihat pada Piagam Makalua BAB I Pasal 1, "Bertugas memajukan usul pandangan kepada pemerintah pusat bahwa Negara Islam Indonesia Republik Kesatuan." Dalam hal ini pun Azis Abdul Qahhar Mudzakkar saat wawancara mengatakan bahwa: ${ }^{20}$ "... sesungguhnya bapak adalah orang yang berpaham negara kesatuan dan hal ini dapat dilihat dari perjuagan beliau di beberapa tempat di luar Sulawesi yang artinya bahwa beliau ingin memerdekakan rakyat Indonesia dari penjajah dan berada dalam satu kesatuan Negara Indonesia."

Dalam Piagam Makalua pun disebutkan khususnya dalam Pasal 2 ayat (1), (2) dan ayat (3) ditegaskan antara hubungan pusat dan daerah dalam bentuk otonomi daerah. Pasal 2 ayat (1): "Supaya diadakan/dibuat undang-undang pokok otonomi daerah-daerah provinsi yang member hak kekuasaan penuh kepada daerah-daerah provinsi membangun dan mengatur dirinya ke dalam." Pasal Ayat (2) menetapkan bahwa: "Supaya diadakan/dibuat undang-

\footnotetext{
18 Wawancara bersama Aswar Hasan pada tanggal 1 Oktober 2012.

${ }^{19}$ Wahid, A. (1999). Politik demi Tuban: nasionalisme religius di Indonesia. Pustaka Hidayah. hlm. 73.

20 Wawancara Azis Qahhar Mudzakkar pada tanggal 30 April 2012
} 
undang pertimbangan keuangan antara pemerintah pusat dan daerah-daerah provinsi (yang disesuaikan dengan sumber penghasilan dan kebutuhan biaya pembangunan)." Pasal Ayat (3): "Kecuali urusan luar negeri, pertahanan negara, dan politik keuangan negara, maka semua urusan kedalam dan kekuasaan pemerintah langsung diatur dan dijalankan oleh pemerintah daerah provinsi."

Dalam menjalankan gagasan mendirikan NII Abdul Qahhar Mudzakkar terus menjalin komunikasi dengan kelompok-kelompok yang tidak sepaham dengan pemerintahan yang dipimpin oleh Soekarno, diantaranya: ${ }^{21}$ Pemerintah Revolusioner Republik Indonesia (PRRI) di bawah pimpinan Syafruddin Prawiranegara, Muhammad Natsir, dan Burhanuddin Harahap. Komunikasi dan komitmen dua kelompok ini akhirnya menyatakan kesepakatan terhadap beberapa konsep negara hukum di antaranya:

1) Ajaran islam dan keimanan kepada Tuhan bagi segenap suku bangsa Indonesia, menurut ajaran syariat agamanya masing-masing;

2) Keadilan sosial sepanjang ajaran islam dan ajaran agama yang dianut oleh golongan suku bangsa di Indonesia, menurut syaiat agamanya masing-masing; dan

3) Demokrasi sejati sepanjang ajaran islam dan ajaran agama yang dianut oleh golongan suku suku bangsa Indonesia, menurut ajaran syariat agamanya masing-masing. ${ }^{22}$

Sekalipun Abdul Qahhar Mudzakkar dari semula tergolong salah seorang penganut paham negara kesatuan namun ia menganggap hal itu bukanlah harga mati, yang menutup diri terhadap perkembangan politik dan sistem ketetanegaraan yang dianggap baik bagi bangsa dan rakyat Indonesia. Sebab baginya hal itu telah digariskan dalam Al-Qur'an dalam surah Al-Hujurat ayat 13, yang artinya: "Hai manusia, Sesungguhnya Kami menciptakan kamu dari seorang laki-laki dan seorang perempuan dan menjadikan kamu berbangsa-bangsa dan bersuku-suku supaya kamu saling kenal-mengenal. Sesungguhnya orang yang paling mulia diantara kamu disisi Allah ialah orang yang paling taqwa diantara kamu. Sesungguhnya Allah Maha mengetahui lagi Maha Mengenal."

Buhari Abdul Qahhar Mudzakkar pun menjelaskan saat diwawancari mengatakan bahwa: ${ }^{23}$ “...memang sesungguhnya bapak berpaham Negara kesatuan namun pada saat bergabung dengan Pemerintah Revolusioner Republik Indonesia (PRRI) di bawah komando Syafruddin Prawiranegara, Muhammad Natsir, dan Burhanuddin Harahap untuk membentuk pemerintahan tersendiri yang pada intinya menyepakati sistem Negara federal."

Bentuk Negara yang digagas oleh Abdul Qahhar Mudzakkar setelah menyatakan diri bagian dari Pemerintah Revolusioner Republik Indonesia (PRRI) adalah Negara Federal sebab baginya hal itu sesuai dengan geografis dan suku bangsa Indonesia yang mejemuk. Saat wawancara Azis Abdul Qahhar Mudzakkar pun menjelaskan bahwa: ${ }^{24}$ “...bapak sesungguhnya berpaham negara kesatuan namun sejak menjadi bagian dari PRRI ia lalu menyetujui bentuk negara federal yang dinggapnya susuai dengan keadaan suku, bangsa dan kepulauan Indonesia."

Kesepakatan Abdul Qahhar Mudzakkar terhadap konsep negara federal karena ia berpandangan bahwa bangsa Indonesia terdiri dari berbagai suku bangsa dan kepulauan. Pembagian negara-negara bagian ia dirumuskannya ke dalam beberapa bagian, yang sebagian besar telah berbentuk wilayah bekas dari penjajahan belanda yaitu: ${ }^{25}$

\footnotetext{
21 Muzakar, A. K. (1999). Op.Cit., hlm. 37-38.

22 Ibid, hlm. 140.

23 Wawancara dengan Bukhari Qahhar Mudzakkar pada tanggal 2 Juli 2012.

24 Wawancara dengan Azis Qahhar Mudzakkar tanggal 30 April 2012.

25 Muzakar, A. K. (1999). Op.Cit., hlm. 131-132.
} 
1) Menurut administrative indeling, Indonesia di masa penjajahan Belanda dahulu dan daerah-daerah tingkat provinsi di Jawa dan daerah-daerah residen di luar Jawa, dengan melalui perhitungan syarat-syarat yang ditentukan dalam UUD negara atas itu, dapat pula dibentuk menjadi negara-negara bagian;

2) Daerah-daerah suku bangsa Indonesia yang besar, seperti Jawa, Madura, Pasundan, Aceh, Minangkabau, Batak, Dayak, Banjar, Bugis, Makassar, Mingkonga-Marunene, Toraja, Buton, Gorontalo, Minahasa, Ambon, Ternate, Irian Barat, dan lain-lain, dengan melalui perhitungan syarat-syarat yang ditentukan dalam UUD negara atas itu, dapat pula dibentuk menjadi negara-negara bagian; dan

3) Dearah-daerah suku bangsa Indonesia yang kecil di luar pulau jawa. Ditambah dengan penduduk yang dipindahkan dari pulau Jawa, dengan melalui perhitungan syarat-syarat yang ditentukan dalam UUD negara atas itu, dapat pula dibentuk menjadi negaranegara bagian.

Dalam Undang-Undang Dasar Republik Persatuan Indonesia (UUD-RPI) menguraikan bentuk dan pembagian daerah berdasarkan daerah-daerah swatantra. Pasal 2 UUD-RPI: "Republik Persatuan Indonesia (Uni-Indonesia) terdiri dari Negara-negara bagian dan daerah-daerah Swatantra." Pasal 3 UUD-RPI: "Wilayah Republik Indonesia meliputi negara-negara bagian dan wilayah daerah-daerah sawtantra."

Mengenai bentuk dan kedaulatan Negara dirumuskan kedalam BAB 1 Bagian I Pasal 1 ayat (1) dan ayat (2) UUD-RPI. Pasal 1 ayat (1) UUD-RPI berbunyi: "Republik Persatuan Indonesia (Uni-Indonesia) yang merdeka dan berdaulat ialah suatu Negara hukum yang demokratis dan berbentuk federasi." Pasal 1 ayat (2) UUD-RPI: "Kedaulatan Republik Persatuan Indonesia ada pada rakyat dan dilakukan oleh pemerintah bersama-sama dengan Majelis Permuswaratan Rakyat." Abdul Qahhar Mudzakkar menjelaskan bahwa apapun bentuk dan susunan pemerintahan Negara itu dapat dibenarkan sepanjang tidak melanggar hukum kedaulatan tuhan dengan tetap berpedoman pada tiga unsur yaitu: Ketuhanan (Agama), Sosial, dan Demokrasi.

Sistem pemerintahan demokrasi sejati adalah "Presidensial" yaitu pemerintahan yang dikepalai oleh presiden selaku kepala pemerintahan dan atau kepala negara bersama dewan pemerintahan yang terdiri dari menteri-menteri yang langsung dipilih oleh rakyat secara demokrasi. Abdul Qahhar Mudzakkar pun menekankan bahwa sistem pemerintahan demorasi sejati di Pusat Pemerintahan Negara berlaku sama dengan sistem pemerintahan di negara-negara bagian, yaitu "kerakyatan" dalam batas kedaulatan hukum Tuhan, menetapkan segala sesuatunya dengan "musyawarah" melalui mekanisme Dewan Perwakilan Rakyat. Ia juga tidak sepaham dengan sistem pemerintahan jika presiden mempunyai hak mutlak dalam kekuasaan beleid pemerintahan (contoh: negara Amerika Serikat), juga ia tidak setuju dengan memperlakukan presiden hanya sebagai "lambang" dan pemerintahan negara diatur dengan "tangan besi" dalam bentuk "Negara Polisi". Ia pun tidak setuju dengan pergantian dewan pemerintahan (Pimpinan Negara) tidak berdasarkan hukum (ia mencontohkan Negara Uni Soviet dan Switzerland).

Aswar Hasan mengatakan bahwa; Abdul Qahhar Mudzakkar menyepakati bentuk negara federal dengan sistem pemerintahan presidensial. Namun Abdul Qahhar Mudzakkar tidak menguraikan secara detail tentang bagaimana sesungguhnya sistem pemerintahan presidensial yang dimaksudkannya ia hanya menjelaskan bahwa sistem pemerintahan presidensial dipimpin oleh presiden dan dibantu oleh para dewan pemerintahan (kabinet). ${ }^{26}$

26 Wawancara bersama Aswar Hasan, pada tanggal 2 Oktober 2012. 
Sistem pemerintahan presidensail yang digagas oleh Abdul Qahhar Mudzakkar tersebut dapat dicermati pada UUD RPI di antaranya: Pasal 63 ayat (1) UUD RPI: "Presiden dan wakil presiden dalah kepala dan wakil kepala negara yang memegang kebijaksanaan kekuasaan pemerintah, selaku pelaksana amanah hukum Tuhan." Pasal 64 ayat (1) UUD RPI: "Presiden dipilih oleh Dewan Perwakilan Rakyat dengan persetujuan Senat, dengan ketentuan bahwa yang terpilih harus mendapat suara sekurang-kurangnya seperdua tambah satu dari jumlah anggota, baik dari Dewan Perwakilan Rakyat maupun senat." Pasal 66 ayat (2) UUD RPI: "Menteri-menteri diangkat dan diberhentikan oleh presiden.” Pasal 66 ayat (3) UUD RPI: "Presiden boleh mengangkat menteri-menteri yang tidak memimpin satu kementerian."

Sebagaimana disebutkan sebelumnya bahwa Abdul Qahhar Mudzakkar menginginkan syariat Islam diterapkan bagi pemeluk-pemeluknya, maka segala UUD-RPI harus bersimbolkan Islam dan presiden haruslah beragama Islam. Hal ini dapat dilihat pada beberapa pasal yang dirumuskan di antaranya: Pasal 63 ayat (1) UUD RPI: "Presiden dan wakil presiden dalah kepala dan wakil kepala negara yang memegang kebijaksanaan kekuasaan pemerintah, selaku pelaksana amanah hukum Tuhan." Pasal 64 ayat (3) UUD RPI: "Presiden dan wakil presiden harus warga negara Indonesia beragama Islam yang telah berusia 35 tahun, dan tidak boleh orang yang tidak diperkenankan turut serta dalam atau menjalankan hak pilih atau pun yang telah dicabut haknya untuk dipilih." Dapat dimengerti bahwa Abdul Qahhar Mudzakkar menginginkan agama bagian dari negara yang bagi Abu Al'Maududi dikatakan sebagai bagian yang integralistik dalam kehidupan berbangsa dan bernegara sehingga segala sesuatunya harus bernilai dan bersandarkan kepada agama (Islam).

\section{Kesimpulan}

Abdul Qahhar Mudzakkar menginginkan negara Indonesia sebagai negara Islam dengan sistem pemerintahan presidensial dengan tetap menjalankan prinsip-prinsip demokrasi sejati. "Demokrasi sejati" diartikan oleh Abdul Qahhar Mudzakkar sebagai bentuk penghargaan terhadap nilai-nilai ketauhidan, pluralitas dan keadilan. Hal ini tentu memerlukan waktu, metode dan penyempurnaan yang lebih baik bila ingin diterapkan di Negara Indonesia yang plural.

\section{Referensi}

Books with an Author:

Moh. Mahfud MD, (2001), Dasar dan Struktur Ketatanegaraan Indonesia, Jakarta: Rineka Cipta.

Muzakar, A. K. (1999). Konsepsi negara demokrasi Indonesia: Koreksi Pemikiran Politik Pemerintahan Soekarno. Darul Falah.

toACCAe Publ.

(2005). Revolusi ketatanegaraan Indonesia: Menudju Persaudaraan Manusia.

Jonaedi Efendi, S. H. I., Johnny Ibrahim, S. H., \& SE, M. (2018). Metode Penelitian Hukum: Normatif dan Empiris. Prenada Media.

Wahid, A. (1999). Politik demi Tuban: nasionalisme religius di Indonesia. Pustaka Hidayah.

\section{Journal articles:}

Purwanda, S. (2014). Model Penanggulangan Konflik Dalam Perspektif Socio-legal (studi Kasus Tawuran Mahasiswa Dikota Makassar) Conflict Management Model in Sociolegal Perspective (Study Case of Student Brawl in Makassar). LAW REFORM, 10(1). 
Amsir Law Jou.3(1)

\section{Conflict of Interest Statement:}

The author declares that the research was conducted in the absence of any commercial or financial relationships that could be construed as a potential conflict of interest.

Copyright $(C) 2021$ ALJ. All rightsreserved. 